International Journal of Social Sciences and Humanities
Available online at http://sciencescholar.us/journal/index.php/ijssh
Vol. 2 No. 2, August 2018, pages: $164 \sim 174$
e-ISSN: 2550-7001, p-ISSN: 2550-701X
https://doi.org/10.29332/ijssh.v2n2.159

\title{
Basir in Religious System of Dayak Hindu Kaharingan Society
}

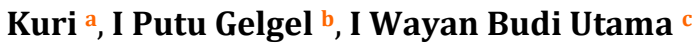

Article history: Received 15 March 2018, Accepted in revised form 10 July 2018, Approved 8 August 2018, Available online 11 August 2018

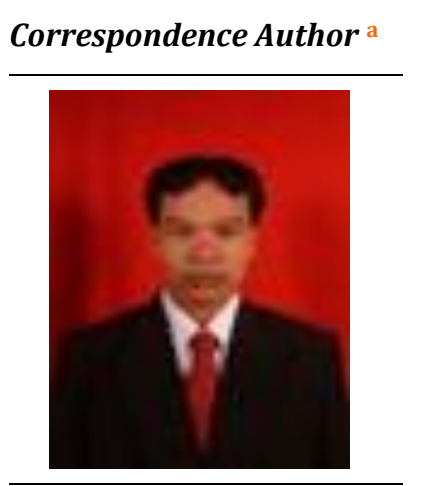

Keywords

Basir;

Dayak;

Religion;

Religious System;

Hindu Kaharingan;

\begin{abstract}
Hinduism developed in Central Kalimantan. It was evidence of Hindu kingdom. It could be seen from the existing history of the oldest Hindu kingdom, namely Kutai kingdom in East Kalimantan in the 4th centuries AD. There was the Yupashaped stone found on the banks of the Mahakam River in East Kalimantan. The Yupa stated that the Kutai kingdom. It was a victim pillar stone that was used to bind sacrificial animals during the ceremony. It was provided evidence of the oldest Hindu in Indonesia. It used the Pallawa letter, Sanskrit (Team, 1996: 14). In accordance with the existing evidence of Hindu kingdom in East Kalimantan, it was also seen in Central Kalimantan. The emergence was Hindu Kaharingan teachings. The emergence of Hindu Kaharingan teachings was a religious system in Dayak society at that time. It was the existence influence of the oldest Hindu kingdom in East Kalimantan. It was developed Hindu Kaharingan teachings in Central Kalimantan. There was inseparable from the belief system that exists in the local Dayak society. One of the local religious elements that were very necessary to be preserved was Basir. Due to Basir was the heir of ancestral teachings from ancient times. It has been determined in Dayak Hindu Kaharingan society in Palangka Raya City. The media was to preserve local religions teachings, one of them was by holding a ritual ceremony led by Basir in the religious system of Dayak Hindu Kaharingan society, especially, in Palangka Raya City. The study was intended to examine Basir in the Religious System of Dayak Hindu Kaharingan society.
\end{abstract}

e-ISSN : 2550-7001, p-ISSN : 2550-701X ๑ Copyright 2018. The Author. SS Journals Published by Universidad Técnica de Manabí. This is an open-access article under the CC BY-SA 4.0 license (https://creativecommons.org/licenses/by-sa/4.0/) All rights reserved.

a University of Hindu Indonesia (UNHI), Indonesia

b University of Hindu Indonesia (UNHI), Indonesia

c University of Hindu Indonesia (UNHI), Indonesia 


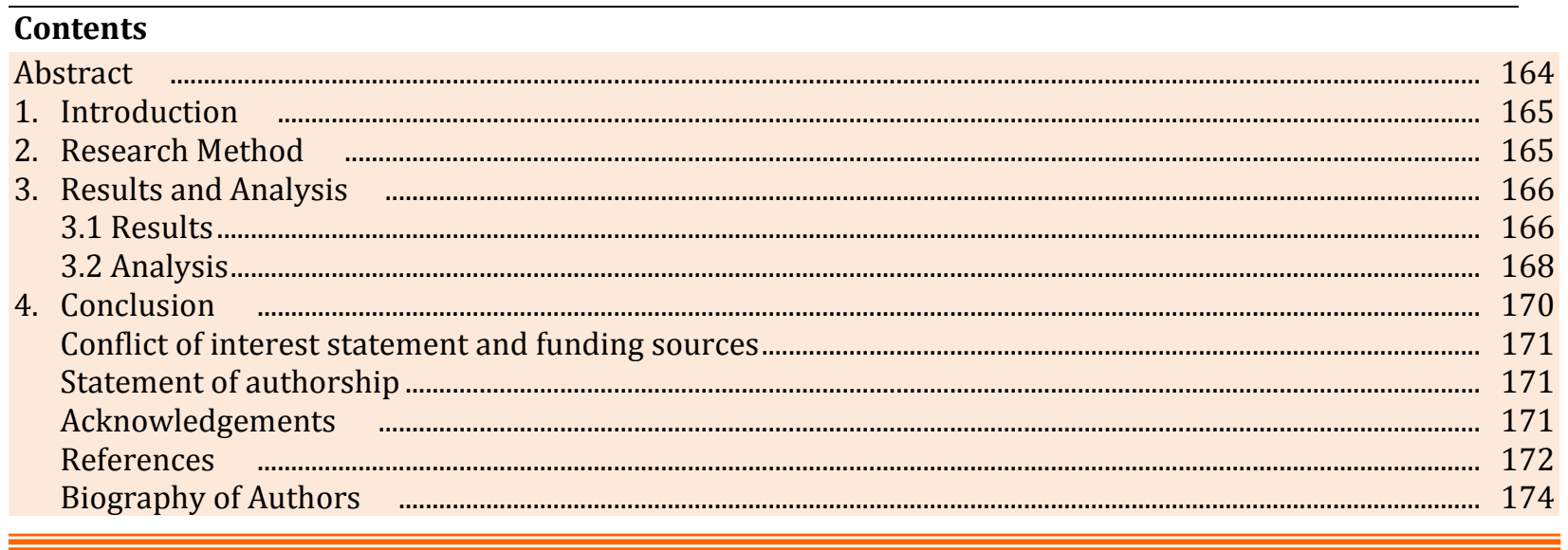

\section{Introduction}

Kalimantan generally and Central Kalimantan particularly, was a very wide island with various kinds of Dayak tribes, with various languages and various kinds of beliefs, and different ceremonies. There was for each region and in each watershed in Kalimantan. Kalimantan consists of seven tribes, the seven tribes, consisting of eighteen tribal children who are in one leader, consisting of 405 family tribes. A belief system was for the Almighty God, in Central Kalimantan of Dayak society was Hindu Kaharingan religion that has developed in progress. Hinduism developed in Central Kalimantan. It was evidence of Hindu kingdom. The existing evidence of Hinduism in Kalimantan can be seen from the existing history of the oldest Hindu kingdom, namely Kutai kingdom in East Kalimantan in the $4^{\text {th }}$ centuries AD. The Yupa-shaped pillar stone found on the banks of Mahakam River in East Kalimantan. It was mentioned Kutai kingdom. Yupa was a victim pillar stone that was used to bind sacrificial animals during the ceremony. It was provided evidence of the oldest Hindu in Indonesia. It used Pallawa letter, Sanskrit (Team, 1996: 14).

In accordance with the existing evidence of Hindu kingdom in East Kalimantan, it was also seen in Central Kalimantan, with the emergence of Hindu Kaharingan teachings. The emergence of Hindu Kaharingan teachings was a religious system in Dayak society at that time. It was the existence influence of the oldest Hindu kingdom in East Kalimantan. It was developed Hindu Kaharingan teachings in Central Kalimantan. It was inseparable from the belief system in the local Dayak society (Edung, et, al. : 2018).

The one effort to preserve the religious system or belief in Dayak society was to keep the local religious elements that were very necessary to be preserved was Basir. Due to Basir was the heir of ancestral teachings from ancient times. It has been determined in Dayak Hindu Kaharingan society in Palangka Raya City. The media was to preserve local religions teachings, one of them was by holding ritual ceremonies led by Basir, in the religious system of Dayak Hindu Kaharingan society, especially in Palangka Raya City (Gepu, et. al. : 2018).

The study was intended to examine Basir in the Religious System of Dayak Hindu Kaharingan society in Palangka Raya City. The study also answered to problems included (1) Why was Basir less desirable in the religious system of Dayak Hindu Kaharingan society? (2) How was the process of becoming Basir in the religious system of Dayak Hindu Kaharingan society? (3) What were the implications of Basir's survival towards the religious system of Dayak Hindu Kaharingan society?

\section{Research Method}

The methods used included the technique of collecting the data i.e., observation, interview, and document study. The technique of analyzing the data used qualitative phenomenological methods in qualitative descriptive research.

Kuri, -, Gelgel, I. P., \& Utama, I. W. B. (2018). Basir in religious system of Dayak Hindu Kaharingan society. International Journal of Social Sciences and Humanities, 2(2), 164-174. https://doi.org/10.29332/ijssh.v2n2.159 


\section{Theoretical framework}

In order to analyze the problems in the present study using four theories i.e., phenomenological and religious theory were used to analyze Basir's less desirable problems, as well as the process of becoming Basir related to the beliefs that exist in the local society. The structural functionalism theory was used to analyze the relationship between the existing structures in the society related to Basir. The reception theory was used to find out the implications of Basir in the religious system of Dayak society in Hindu Kaharingan adherents.

\section{Results and Analysis}

\subsection{Results}

The result of the study was included the three aspects:

1. The factors of Basir were less desirable in the religious system of Dayak Hindu Kaharingan society in Palangka Raya City. Basir was less desirable included: internal factors and external factors.

\section{(a) Internal factors}

Sangiang language used by Basir. The following was an example of the Sangiang language used to name of the "God" Ranying Hatalla Langit, Raja Tuntung Matan Andau, Tuhan Tambing Kabunteran Bulan. For some people did feel the Sangiang language as an obstacle in learning of Balian or becoming Basir. The interest was supporting factor become Basir, if someone who will pursue the profession as Basir, they ought to have a strong interest in being able to become Basir. It was an interest factor. It then was very important and a major factor in the learning process, pursuing life as someone clergy/Basir Hindu Kaharingan. Due to the interest supported so that someone's heart was the main factor as a motivator or encouragement if the person has the desire to learn to live as a spiritual/Basir. If there was no possible interest the person can succeed, which able to lead ceremonies, especially for Hindu Kaharingan people in Palangka Raya City.

The talent was a factor that influences a person to become Basir. If there was no talent, it then was impossible for the person to become Basir. As people servants, in leading various ceremonies, which was in Hindu Kaharingan people in Palangka Raya City. The knowledge could also be an obstacle for beginners or for someone who has just learned to become Basir, but for someone who has learned a lot both verbally and writing. Basir knowledge was not an obstacle or a barrier to becoming Basir. The family factors were also important factors for one's success in all things, as well as, the success of being Basir, there surely was also moral and material support from the family. Without family support, it was very unlikely that someone will succeed or be successful become Basir. The psychology factor was very important. Due to without being supported by a biological healthy and physical healthy, it would not be possible for someone to be able to become Basir. It was different if someone has a miracle/inspiration from Sangiang/God. Having talent from birth, there were no obstacles or distortion for the person learning become Basir.

\section{(b) External factors}

Economic factors, in carrying out the ceremony very little influence due to someone who has a strong desire supported by the interest and talent to become Basir was not an economic factor as an obstacle. Basir has a noble duty in carrying out various ceremonies, in essence, not everyone could and was able to become Basir, without the natural talent was in them, as well as the soul would carry out these tasks. Education factors, the formal and non-formal education was to determine the direction or mindset of a person went to the next life. Likewise, someone's education, related to life as a clergy also has a future contribution, to determine the direction and way of life that would be passed. Education was really needed by everyone, therefore, education was a basic capital, in the social life. Although education was not very influential, on one's interest in becoming Basir. The education factor for someone who has a strong desire, learning Basir, there was no influence, constraints or impact on education. Due to Basir in ancient times, very few received an education. In fact, the most of them were Basir, no one has a high school education equivalent, but they could read and write, and were able to lead Balian ceremony. 
The social change factors, the changes that exist in the society could bring good (positive) and adverse (negative) impacts, the good impact for someone would bring progress for themselves in learning to be Basir. The negative impact would have an unfavorable impact on them to pursue life as Basir, as well as Basir sustainability it also does not escape that impact. Social Factors, due to the social changes and influences, thus, Basir would decrease. If Basir decreased, then the service of the society at certain times, wherein the people needed Basir to lead the ceremony. There was a delay in every Hindu Kaharingan religious ceremony. As well as the worst thing, the faith of the people towards Basir/clergy would decrease, so that, the people gradually will convert or enter another religion. Cultural factors, the culture that exists in Dayak society was different. It was unique and rare when viewed in the life of Dayak society. The cultural factors that exist in the Dayak society did not have much impact or influence on the development of learning Balian to become Basir.

There was an influence precisely from outside culture, for example in marriage ceremonies, there was often a wedding reception with local songs or Dayak songs as well as Dayak dances. The era development, the regional songs, and regional dances were replaced with free dance/joget or with western music which would eliminate local culture. The customary factors exist in Dayak society, Hindu Kaharingan, there was no influence on the Balian learning process, precisely with strong customs. It would be increased the interest in learning Balian. The custom was in the wedding ceremony, e.g., manyaki mamalas panganten ceremony (purifying the bride and groom) with animal blood (chicken, pig) carried out by Basir or by Mantir Adat. The implementation of the customary marriage was still carried out by Hindu Kaharingan society in Palangka Raya City. Due to the traditional customs that exist in Hindu Kaharingan society still exist, with the time's development, although it has long been taught and developed from the ancestors of Dayak society to the day.

2. The procession becomes Basir in the religious system included:

(a) Preparing facilities and infrastructure for Basir inauguration ceremony, the ceremony tools (Sarana and Prasarana) needed to be prepared during the ceremony to be Basir, in Palangka Raya City, namely: Katambung/drum, Katil/a sit Basir, Garantung/gong/Balinese instruments, amas sakaping/gold 2,700 milli, sinde mendeng clothes/one pack of cloth and manuk jagau ije kungan/a male chicken ".

(b) Determining the time and place for the Basir inauguration ceremony to be held, the implementation of Basir inaugural ceremony, carried out at the local society's house or at the house that has been agreed upon of Balian participants or can also be at the worship hall (Balai Basarah). During the inauguration ceremony, someone becomes Basir, usually choosing a good day, avoiding Tuesday because the day was not good according to Dayak culture (due to Tuesday means Sala/wrong) and not in the night. Choosing when the moon was soft (the moon appears in the sky) not during the munus moon (when the moon is tilem (not dark), at that time the ceremony was very well carried out.

(c) Preparations series for the implementation of Balian Mampendeng Sawang Garu ceremony (Basir inauguration ceremony). The initial phase prepared 63 facilities for inaugurating Basir from the beginning of the activity until the activity end. The second stage prepared the facilities for Balian Tantulak Dahiang ceremony/to expel and eliminate the negative influence during the race ceremony. The third stage prepared 14 (fourteen) facilities to establish the Balai Palangka and Ancak Mihing, and directly held Balian ceremonies.

(d) The abstinence after Basir's inaugural ceremony "there were several pali or abstinence after Basir's inauguration ceremony was carried out, as for Pali or abstinence, these were: There was pali/abstinence for 1 (one) week, and there was also pali/restrictions for 3 (three) month ".

(e) The impact of some abstinence, Malai, experiencing illness/fever. Everything learned was of no benefit and was no use. Having bad luck or misfortune in his life and not getting taksu/glory from God and death experience.

3. Implications of Basir's sustainability in the religious system of the Hindu Kaharingan Dayak society in the City of Palangka Raya. Implications Basir's continuity with the religious system included:

(a) The implications of Basir sustainability towards Hindu Kaharingan society would have a social impact which has close relations with each other. The same goes for the social institutions (Majelis Besar Hindu Kaharingan/MB-AHK) as well as the service of the Hindu Kaharingan society in the Balian ceremony. In

Kuri, -, Gelgel, I. P., \& Utama, I. W. B. (2018). Basir in religious system of Dayak Hindu Kaharingan society. International Journal of Social Sciences and Humanities, 2(2), 164-174. https://doi.org/10.29332/ijssh.v2n2.159 
fact, there would be religious reform (religious conversion) from Hindu Kaharingan religion to other religions. It would be delayed in any service related to several ceremonies.

(b) The implementation of Basir sustainability will be delayed in each service related to several existing ceremonies.

(c) The implications of Basir towards the belief system and the process become Basir would reduce faith and trust who will act in other religions and difficulties in every ritual/ceremony. Due to Basir was rare.

(d) The implications of Basir sustainability in building awareness. There would be a shortage of Basir for those time and in the future and would be hampered by the next regeneration and Basir development itself as well as the impact on the ritual/ceremony.

(e) The implications for Basir sustainability in carrying out various ritual ceremonies included:

1) Implications of Basir sustainability of the Manawur ceremony for Dayak Hindu Kaharingan society. It did not experience an adequate impact or had little impact on the ceremony.

2) Implications of Basir sustainability about the annual ceremony. It was not too constrained and impacted due to the ceremony could be carried out by the village midwife and the person in the family, if Basir was unable or could not lead the annual ceremony.

3) Implications of Basir sustainability regarding the Marriage Ceremony of Dayak Hindu Kaharingan society, it was not very influential and did not have a significant impact on them. Even though without Basir who carried out the Hindu Kaharingan marriage ceremony but could be replaced by customary leaders/customary mantirs and customary demang chiefs as well as people who were competent in carrying out the wedding ceremony.

4) Implications of Basir sustainability of Pakanan Sahur Parapah ceremony of Dayak Hindu Kaharingan society, due to was in dire need of Basir. Therefore, for the ceremonial process, it could run well and Basir played an important role if Balian ceremony was held. But if there was only use Tawur/Manawur, for Pakanan Sahur Parapah ceremony itself, they did not lead by Basir in the activity.

5) Implications for Basir sustainability of the Manyanggar/Balian Mapas Lewu ceremonies in Dayak Hindu Kaharingan society, there was a huge influence or impact on the ceremony sustainability due to Basir was the one who played an important role in leading the ceremony.

6) Implications of Basir sustainability of Balian Tantulak Ambun Rutas Matei ceremonies for Dayak Hindu Kaharingan society, it was very influential and significant for Hindu Kaharingan people, especially, in Palangka Raya City. It was constrained by the lack of Basir, therefore, it was often hampered and late in carrying out the death ceremony. If it occurred in Palangka Raya City, it would undoubtedly have a bad effect on the Dayak people, especially for Hindu Kaharingan, as well as for Dayak society generally.

7) Implications of Basir sustainability for Tiwah ceremony of Dayak Hindu Kaharingan society, there was less impact on although there was no significant effect on the people. The most of the ceremonies were in accordance with the instructions carried out by the family before carrying out Tiwah ceremony itself.

\subsection{Analysis}

\section{Definition of Basir}

Basir/Pisor was the name of a clergy of Hindu Kaharingan people who have an honorable position. Due to the task of carrying out Hindu Kaharingan religious ritual ceremony called Ulama Kaharingan (Team, 2007: 9). Basir was unlike like Balian. They were human mediator and communicator with other beings whose existence was not visible to the real world. In the past, the Basir was a man who behaved like a woman, but for the present time, it was no longer believed. Basir in the spiritual world has more abilities, in terms of treatment, especially, disease healers related to the mystical phenomenon (Riwut, 2003: 259-260).

According to Mahin, (2009: 60), there were four levels Kaharingan belief called Basir, included:

1) Tukang Hanteran: The chief priest who was in charge of performing the hateran was the ceremony to take the spirit of the deceased person into heaven (lewu tatau). 
2) Basir Upu: The Main people who were the leader of the priests when conducting Balian ceremony usually consisted of 5 (five), 7 (seven), 9 (nine) priests.

3) Basir Pangapit: The accompanying of a priest who served together with Basir Upu, in the ceremony sat in the left and right side of Basir Upu.

4) Basir Pangiring: Basir candidates who are learning to become Basir, in their ceremony was Lawin Katil which was at the end of the seats of Basir Upu and Pangapit.

Basir was mentioned as a clergy who was able to lead various rituals that existed in the Dayak tribe.

\section{Religious system}

The lexicon system comes from the Greek "systema" which has defined (a) the whole composed of many parts; (b) the relationships that take place between units or components regularly. Therefore, the other term lexicon "systema" defined a set of parts or components that were interconnected regularly and constitute a whole Tan, M. G., \& Penelitian, M. P. (1991). According to Emile Durkheim (2010), interpreted that religion as the people connection to do something, it was considered sacred which served as a strong symbol of the society and the people interdependence in the society concerned.

Religion has defined a trust to the God. The belief was the existence of supernatural powers above humans; trust (animism and dynamism). A religious system in a culture always has the characteristics to maintain the religious emotion as much as possible among its followers. Thus, the religious emotion was an important element in a religion along with three other elements, included (1) belief system; (2) a system of religious ceremonies; (3) a people who embrace the religion (Koentjaraningrat, 1990: 377). Concerning the religious system of Dayak society who have various religious systems or beliefs that have existed since time immemorial, Dayak called religion was helu/or religion formerly known as Hindu Kaharingan religion (Hindu, T. P. B. P. A. (1996).

\section{Dayak society}

According to Durkheim in (Koentjaraningrat, 1987: 87), regarding society was the view of a living for the society. There were people who think and behave in relationships with one another. According to Karl Marx (2015), the society notion was a structure that experienced organizational or developmental tension due to the opposition between economically divided groups. According to M. J. Herkovits (2015), society understanding was a group of individuals who were organized and follow a particular way of life. According to J. L. Gillin and J. P. Gillin (2015), the society notion was a group that was to spread with the same feeling of the unity. According to Max Weber (2015), the society notion was a structure or action that was principally determined by the expectations and values that are dominant in its citizens. According to Selo Soemardjan (2015), society understanding was people who live together and produce culture. The society understanding was a group of people who were relatively independent by living together for long periods of time, inhabiting a certain area with the same culture, and most of the activities in the group. The term "Dayak" is a social term in Kalimantan. Everyone even throughout Indonesia who hears the word Dayak, certainly their mind tribes in Indonesia inhabits in Kalimantan (Riwut, 2003: 57).

Dayak society was a group of people who inhabit an island (Kalimantan) with a variety of customs, cultures, and tribes, and languages. Therefore, it was called the Dayak society or Kalimantan Dayak tribe.

\section{Hindu Kaharingan}

The lexicon Hindu comes from Greek, Hydros, or Hidos and as a name to mention the culture or religion that developed in the Sindhu River Valley (Awanita, 2003: 5). The beginning of the term Kaharingan, since the establishment of SKDI (Syarikat Kaharingan Dayak Indonesia) organization, it was established on July $20^{\text {th }}, 1950$ at Sampit, in Central Kalimantan. The Kaharingan institution was established in Central Kalimantan in 1972, named MBAUKI (Majelis Besar Alim Ulama Kaharingan Indonesia). There organizationally was no link between SKDI and MBAUKI, but it was probable that a new institution was changed from SKDI to accommodate the intense struggle for their trust was recognized by the State. After December 1979, MBAUKI held a large meeting.

Kuri, -, Gelgel, I. P., \& Utama, I. W. B. (2018). Basir in religious system of Dayak Hindu Kaharingan society. International Journal of Social Sciences and Humanities, 2(2), 164-174. https://doi.org/10.29332/ijssh.v2n2.159 
They succeeded in reaching the agreement. Kaharingan was recognized as one of the religions by the State. However, the conditions at that time did not allow the existence "other religions" the outside five religions recognized by the State. The reason was Central Kalimantan Regional Office, the Department of Religion suggested that Kaharingan was similar with Hindu. It perhaps due to the government agency saw similarities between Kaharingan and Hinduism. The MBAUKI accepted the suggestion. The MBAUKI then changed its name to the Hindu Kaharingan Religious Council, on dated March 30 $30^{\text {th }}, 1980$ the inauguration of the board's management. After being processed by the Central Kalimantan Regional Office, the Ministry of Religion, finally on April 28 ${ }^{\text {th }}, 1980$, the Minister of Religion of the Republic of Indonesia issued a Letter number MA/203/1980 stated that the approval of Kaharingan followers to join Hinduism (Laksono, et al., 2006: 45-48).

After finding similarities for the differences in religious practices of Kaharingan and Hinduism generally, the similarities and differences were closely related to the development system of Hinduism. Hinduism developed following the "village/desa", "time/kala" and "state/patra". The existence of culture and tradition was a wrapper for Hinduism. As the result, Hindu religious practices were different in one area. The rise of religious practices made the perpetrators and implementers of Hindu teachings whose understanding was lacking in Hinduism become foreign to Hinduism. Even, they did not realize what they actually did in Hindu teachings. They had a desire to unite with Hinduism when they had realized that Hinduism was practicing in the past. At the time, MBAUKI was always struggled to get Kaharingan legality as Religion to the Government even though they had succeeded in making the Panaturan Scriptures. They always failed to get the legality. Therefore, the Kaharingan leaders took another method to find legality. There finally was the integration of Kaharingan with Hinduism with the issuance of a Decree of the Hindu and Buddhist Community Guidance, the General of the Ministry of Religion of the Republic of Indonesia No: H/37/SK/1980 dated July 19 th, 1980 concerning Inauguration (MBAHK) Majelis Besar Agama Hindu Kaharingan as a Religious Board. After integration with Hinduism, Kaharingan integrated to unite with Hindu society in Indonesia. It was also to obtain formal juridical recognition and protection from the Indonesian government. Considering they haven't gotten it yet. After integration, the "Kaharingan" became the "Hindu Kaharingan" religion that existed until now in Central Kalimantan (Penyang, et al, 2003: 10-11).

Based on the above opinions, then in the present study, the researchers explored Basir in the Hindu Kaharingan religion which had something to do with the local religious system related to local wisdom (local genius). It was developed in the Hindu Kaharingan society in Palangka Raya City.

\section{Conclusion}

It can be concluded three points:

1) The factors of being less desirable become Basir, the process of being Basir in the religious system of Dayak Hindu Kaharingan society, and the implications of Basir's progressed religious system. It was due to the internal factors and external factors. The internal factors included language, interest, talent, knowledge, family, and psychology. The external factors included community, social, and economic changes. Based on these factors, the perspective of the phenomenological theory was a relevant theory to analyze the problems mentioned above related to the phenomena that exist in the Dayak Hindu Kaharingan society in Palangka Raya City.

2) The process of becoming Basir in the religious system of Dayak Hindu Kaharingan society included preparing the facilities and infrastructure of Basir's inaugural ceremony, determining the time and place for the inauguration ceremony of Basir, Pawaran after the inauguration ceremony of Basir and the impact of some restrictions. In accordance with the procession, the implementation takes place regularly and consistently based on the rules contained in the teachings of the Hindu Kaharingan Religion. It means that religious theory was in accordance with the reality that occurred in the religious system of Dayak Hindu Kaharingan society, as well as the structural functionalism theory, which emphasizes the order in which each structure was always functional with each other, visible in the religious system of the Dayak society.

3) the implications of Basir survival towards the religious system of Dayak Hindu Kaharingan society included: implications of Basir sustainability towards Hindu Kaharingan social institutions, implementation of Basir sustainability towards the Life of Dayak Hindu Kaharingan, implications of Basir sustainability towards the belief system and the process of becoming Basir, implications for sustainability Basir developed awareness of Hindu Kaharingan society, implications for Basir sustainability in carrying out various ritual ceremonies 
in Palangka Raya City. Based on the implications of Basir's sustainability, the reception was a ground theory to analyze the implications of the Basir sustainability on the religious system. It, therefore, can be seen the implications that occurred, due to the stagnation or crisis to Basir sustainability in carrying out the ceremony.

\section{Findings}

The findings were theoretical and practical. There were two theoretical findings, namely:

1) This researcher affirmed the structural functionalism theory, that was functional would still exist while the dysfunction would disappear by itself. Basir still exists due to they were functional in the ritual of Dayak Hindu Kaharingan society.

2) This study also affirmed the religious theory in Dayak Hindu Kaharingan society it was still maintained the existence of local religious systems even though the state has set six (6) formal religions, namely: Islam, Protestantism, Catholicism, Hinduism, Buddhism, and Confucianism.

There were two practical findings, namely:

1) The interest of Hindu Kaharingan society to become Basir can be stated a little bit, but thanks to the intervention of the Sekolah Tinggi Agama Hindu Negeri Tampung Penyang (STAHN-TP) Palangka Raya, Majelis Hindu Kaharingan (MB-AHK) and Regional Government (PEMDA) for held Basir training, then the existence of Basir still remains today.

2) The language and symbols used by Basir were still maintained, unlike Sangiang language, although the public has not understood the meaning and sense.

Conflict of interest statement and funding sources

The authors declared that they have no competing interest. The study was financed by personal funding.

Statement of authorship

The authors have a responsibility for the conception and design of the study. The authors have approved the final article.

Acknowledgments

The authors thank the editor of the IJSSH for their support, advice, and valuable time.

Kuri, -, Gelgel, I. P., \& Utama, I. W. B. (2018). Basir in religious system of Dayak Hindu Kaharingan society. International Journal of Social Sciences and Humanities, 2(2), 164-174. https://doi.org/10.29332/ijssh.v2n2.159 


\section{References}

1. Awanita, IM. (2003). Agama Hindu Modul Orentasi Pembekalan Calon PNS Biro Kepegawaian. Jakarta: Sekretariat Jendral Depag RI.

View in (Google Scholar)

2. Edung, T., Triguna, I. B. Y., \& Utama, I. W. B. (2018). Balian Wara position of Dayak Lawangan. International Journal of Linguistics, Literature and Culture (IJLLC), 4(4), 103-111.

View in (Google Scholar)

3. Gepu, W., Suda, I. K., \& Suyasa, I. M. (2018). Religious conversion towards Hindu Kaharingan to Christianity. International Journal of Linguistics, Literature and Culture (IJLLC), 4(4), 25-37.

View in (Google Scholar)

4. Gillin, J. L., \& Gillin, J. P. (1942). An introduction to sociology. Macmillan.

View in (Google Scholar)

5. Herkovits, J., \& Helguero, L. A. (1998). Copper toxicity and copper-zinc interactions in amphibian embryos. Science of the total environment, 221(1), 1-10.

View in (Google Scholar)

6. Hindu, T. P. B. P. A. (1996). Buku Pendidikan Agama Hindu untuk PerguruanTinggi. Jakarta: Hanoman Sakti. View in (Google Scholar)

7. Indonesia, L. I. P. Koentjaraningrat, 1987. Sejarah Teori Antropologi I.

View in (Google Scholar)

8. Koentjaraningrat, \& Cornell University. Modern Indonesia Project. (1967). Villages in Indonesia. Cornell University Press.

View in (Google Scholar)

9. Koentjaraningrat, R. M. (1994). Kebudayaan, mentalitas, dan pembangunan: bungarampai. Gramedia Pustaka Utama.

View in (Google Scholar)

10. Koentjaraningrat. (1957). A preliminary description of the Javanese kinship system (Vol. 4). Yale University, Southeast Asia Studies.

View in (Google Scholar)

11. Laksono, I., \& Chan, J. (2006). U.S. Patent No. 7,042,941. Washington, DC: U.S. Patent and Trademark Office. View in (Google Scholar)

12. Mahin, M. (2009). Kaharingan dinamika agama Dayak di Kalimantan Tengah (Doctoral dissertation, Universitas Indonesia. Fakultas Ilmu Sosial dan Ilmu Politik).

View in (Google Scholar)

13. Penyang, Simal, dkk. (2003). Bahan Ajar Panaturan I. Palangka Raya: STAHN-TP. View in (Google Scholar)

14. Penyusun, T. (1996). Buku Pendidikan Agama Hindu Untuk Perguruan Tinggi. Jakarta: Hanuman Sakti. View in (Google Scholar)

15. Riwut, T., Mantikei, S., \& Riwut, N. (2003). Maneser panatau tatu hiang. Pusakalima. View in (Google Scholar) 
16. Soemardjan, S. (1991). Perubahan Sosial. Yogyakarta: Gadjah Mada University. View in (Google Scholar)

17.Tan, M. G., \& Penelitian, M. P. (1991). dalam Koentjaraningrat. Metode-Metode Penelitian Masyarakat, Jakarta: Gramedia Pustaka Utama.

View in (Google Scholar)

18. Weber, M. (2015). Soziologische grundbegriffe. BoD-Books on Demand.

View in (Google Scholar)

Kuri, -, Gelgel, I. P., \& Utama, I. W. B. (2018). Basir in religious system of Dayak Hindu Kaharingan society. International Journal of Social Sciences and Humanities, 2(2), 164-174. https://doi.org/10.29332/ijssh.v2n2.159 


\section{Biography of Authors}

\begin{tabular}{|l|l||}
\hline \hline & $\begin{array}{l}\text { Kuri, S.Ag., M.Ag. was born in Rodok, December 20th, 1967. He is a lecturer as well } \\
\text { as a civil servant. He lives at Jalan G. Obos XVI E No. 124 Palangka Raya. } \\
\text { Email: kuri7212@gmail.com }\end{array}$ \\
\hline \hline & $\begin{array}{l}\text { I Putu Gelgel is a professor at the University of Hindu Indonesia Denpasar. } \\
\text { Email: putu.gelgell5@ gmail.com }\end{array}$ \\
\hline \hline & $\begin{array}{l}\text { I Wayan Budi Utama was born in Denpasar, January 15th, 1958. He is a lecturer at } \\
\text { the University of Hindu Indonesia. } \\
\text { Email: budiutama904@gmail.com }\end{array}$ \\
\hline
\end{tabular}

